\title{
A Cultural Heritage Management Perspective: Kotabaru, Yogyakarta, Between a Protected Cultural Site and a Commercial Area
}

\author{
Fahmi Prihantoro \\ Department of Archeology, Universitas Gadjah Mada, Indonesia \\ Email: fahmiprihantoro90@gmail.com
}

\begin{abstract}
Yogyakarta's Kotabaru area is one of rich cultural heritage, with a protected cultural status that means it must be preserved. Presently, Kotabaru faces the threat of destruction as a consequence of its developing business and services sectors. The changing of building functions, together with new developments, is ever-increasing with each year. This research sought to study what is occurring between the preservation of the Kotabaru area and the development of its economic sector, as well as how efforts can be made to solve the problems of the threat of destruction to protected cultural sites within the area, using the Historic Urban Landscape (HUL) approach. The findings revealed that there are competing interests in the Kotabaru area, between preservation and economic development, which contribute to the emergence of a threat to the preservation of protected cultural sites. To solve this problem, the HUL approach should be used and, in particular, the approach contained in the UNESCO recommendation on managing cultural heritage. With these findings, it is hoped that they will be able to serve as a reference concept for the solving of the issues that are occurring in the Kotabaru area, from a perspective of cultural heritage management.
\end{abstract}

Keywords: cultural heritage management; Historic Urban Landscape; Kotabaru Yogyakarta

\section{INTRODUCTION}

Kotabaru Yogyarkarta is known as an elite residential area which was built in the Dutch Colonial period. The region is the one and only residential area in Yogyakarta which was developed using the concept of the Garden City (Ikaputra, 2017:10) which emphasizes the dominating presence of green areas in a residential area. To date Kotabaru can still be seen to be a residential area which is dominated by stands of trees both in the yards of buildings and on the sides of streets with various buildings with Indies architecture with a colonial nuance. From another side, the Kotabaru area has begun to be threatened by the everincreasing presence of new buildings which is predicted will threaten the character of the image of an area with a Garden City concept together will the presence of Indies style buildings within it.
The Kotabaru area has been designated by the government as a protected cultural area (Kawasan Cagar Budaya - KCB) in Gubernational Decision No. 186 of 2011. This regulation arose as a follow-on effort from the promulgation of Republic of Indonesia Act No. 11 of 2010 Concerning Protected Cultural Areas (UndangUndang Tentang Cagar Budaya-UUCB) which tries to protect various cultural heritage in the form of objects, sites and areas. Another consequence of the UUCB is the Kotabaru protected cultural area, with its various cultural heritage aspects comprising buildings and a landscape with the Garden City concept, which has important values which must be preserved. But on the other hand, the Yogyakarta City Government has to the contrary designated the Kotabaru area as a business and 
services zone area based on Yogyakarta City Regional Regulation No. 1 of 2015 Concerning Space Management Detailed Plan (Rencana Detail Tata Ruang (RDTR) and Yogyakarta City Zoning Regulation (Peraturan ZonasiPZ). These two policies have resulted in the existence of two different things being in effect in one area. Kotabaru, as a protected cultural area, will be preserved by limiting new developments which are not in accord with the regulations, on the other hand Kotabaru, as a business and services area, has been allocated as an extensive space for developing of various businesses which often need a new design or to change old, existing buildings. The situation is becoming increasingly difficult when there is already another regulation that is, City Mayor Regulation No. 25 of 2013 Concerning Building Basic Co-efficient (Koofisien Dasar Bangunan - KDB) in the Kotabaru area which allows a maximum of $90 \%$. This is coupled with the emergence also of other regulations which permits the development of buildings to a height of 32 meters in a business and services zone that is, City Mayor Regulation No. 53 of 2017. In this way it allows, based on the regulations, a building in the Kotabaru area to be a maximum of eight floors as well as putting aside just $10 \%$ for a green area. From these several aspects above, it will certainly have an impact on the Kotabaru area preservation efforts including buildings which are located within it.

Several previous research papers concerning Kotabaru area indicate that the area faces challenges of change associated with its use of space. A challenge which is very real are instances of usage for places of business which often demands changing the structure of the building to following current trends. This matter will influence the architectural image of the Kotabaru area which will be disturbed as a protected cultural area (Hadiyanta, 2017:18-19). In the meantime, Kotabaru will also face the problem of the destroying of the character of the area because of the existence of the KDB which determines $80 \%$ for residential purposes and $90 \%$ for business purposes. The Kotabaru area, as a protected cultural area with its Garden City concept, is predicted to experience damage by the existence of these policies mentioned earlier because little by little it will cause the loss of the green zone (gardens) which have become a special feature of Kotabaru (Ikaputra, 2017: 13). Kotabaru changes have also occurred in its building function and if building damage should be between $30-60 \%$ its is feared it will damage the character of the protected cultural area (Suparwoko, 2016:513; Wahyu, 2011:217). The change of building function in the Kotabaru area has also occurred as a result of the changing of its usage in particular, for commercial interests (Umezo, 2001, Yose, 2005). In relation to determining the significance of the city protected cultural areas there also needs to be a relation between the genius loci, which constitutes its historical identity and the significance of the building as a basis to develop a heritage area (Daldanisa, 2016:105). Apart from that, the managing of the Kotabaru area does not yet have sound planning in accordance with sustainable conservation principles which thinks about cultural heritage over the long term (Wahyu, 2011:191).

Several studies have been done which further highlight the threat of damage to the character of Kotabaru as a protected cultural area and the various changes which have occurred in relation to building function and form. There are not yet many studies which connect how the phenomenon of conservation and change have been solved concurrently by means of a win-win solution, taking in various aspects of wider interests. Research, which connects Kotabaru, as a protected cultural area which must be preserved, with the emergence of other interests such as commerce and tourism is important work to be done. Can the protected cultural area be synchronized with various other interests without sacrificing the existence of this cultural heritage so as it can keep being understood collectively and thus accorded a significance by its supporting community now and into the future? This research aims to answer the problem as a consequence of what has emerged in the Kotabaru area with its status as a protected cultural zone and a commercial zone. Apart from this, the research also has the aim of answering how the concept of cultural heritage management can accommodate various existing interests. This research gives rise to the hypothesis that differences of interests occurring in the Kotabaru area as a protected cultural area and as a commercial area can be brought together in a management concept which accommodates both these interests through the HUL approach.

\section{RESEARCH METHOD}

Cultural heritage management, which later became known by the term Cultural Resources Management $(C R M)$ in archeology, began to be developed in America in the 1980s. It started from a concern over various threatened archeological remains which experienced damage from development activities which continued unabated. Consequently it was necessary to think about how to preserve, to manage and to use so as to guarantee its existence as long as possible (Gimsey and Davis, 1997:24; Darvill, 1987:4). In its development, CRM not only thought of just cultural heritage management 
but also stressed the importance of the involvement of the community in this management so as to increase the feeling of their ownership (McKercher \& du Cros, 2002:45).

This research uses the HUL approach which is one of the approaches in the management of cultural heritage as a basis to solve existing problems. The HUL concept, which has been chosen for this paper, is in essence cultural heritage management which emphasizes various elements which are developed comprehensively. The concept stresses a management concept which accommodates various elements and an area (landscape) both in the form of objects, such as buildings, open space, layout and intangibles such as philosophy, social condition, traditions, and culture (Bandarin dan Oers, 2012). Research with a HUL approach in Indonesia is still relatively sparse and only used in the context of what is done for development and conservation of an area (Asriana dan Sesotyaningtyas, 2018: 51-57; Rauzi dan Dewi, 2017: 52-58; Prabowo, 2020; Timmer, 2018). In the meantime, to date the management of cultural heritage places more emphasis on monumental objects within an area which has to be preserved but without looking at the context of the building. Apart from that, the management concept is based more on regulations which become government political policy which views cultural heritage more as an object which has to be preserved (Puckzo, 2006:240; Ratz, 2005:133). In the case of the Kotabaru area, Yogyakarta there is a strong domination by the regulations as a cultural heritage management reference which still views cultural heritage as an object as contained in the regulations of Law No. 11 of 2010 Concerning Protected Cultural Areas and several regulations at the regional level including those which are in the Special Area of Yogyarkarta (Daerah Istimewa Yogyakarta-DIY). This is the very reason why this research uses the HUL approach which is more comprehensive in cultural heritage management efforts in the Kotabaru area, Yogyakarta.

The regulations which are the basis for cultural heritage management is found in Republic of Indonesia Act No. 11 of 2010 Concerning Protected Cultural Areas. Later various subsidiary regulations emerged at the regional level which also emphasized cultural heritage conservation efforts of objects. In particular, in DIY there later emerged several regulations such as DIY Provincial Regulation No. 6 Concerning Cultural Heritage Conservation and the DIY Provincial Regulation No. 1 of 2017 Concerning Building Architecture with Special DIY Characteristics. Meanwhile on one hand, given the changes in an area over time it is certain what occurs also includes changes to building use. At the same time the community, as the direct owners, are not greatly involved in cultural heritage conservation efforts even though the presence of the community is a factor in determining the continuation of cultural heritage (Hooder, 1999: 171).

This research uses a qualitative model with a descriptive analysis. The data collection technique is observation which records various cultural heritage objects in Kotabaru in the form of the landscape, buildings, street networks, historical monuments, and intangibles in the form of various community activities at this time connected to the Kotabaru protected cultural area. Interviews were also conducted with the owners of protected cultural areas, government agencies, business people and the community who live in and outside Kotabaru. Apart from this, data was also obtained from literature studies, old maps, and relevant legislated regulations.

The interpretation was done by using four components in the HUL which are contained in UNESCO Recommendation 2011 which consists of: 1) community engagement, 2) knowledge and planning, 3) regulatory system, and 4) financial tools. Furthermore, various data which has been classified, contextualized with each other by referencing the four HUL components to facilitate new interpretations in answering the research problem. At the end, after a process of analysis and interpretation is done, a conclusion is derived.

\section{RESULTS AND DISCUSSION Kotabaru as a Protected Cultural Area \\ Kotabaru Possessing Special Characteristics of Garden City Concept}

The Kotabaru area was established in 1917 by a letter Rijksblad van Sultanaat Djogjakarta No. 12 of 1917. Meanwhile its development was undertaken by Departement van Sultanaat Werken which was chaired by Ir. (Engineer) L.V.R. Beekveld (Dingemans, 1926: 7, 16; Junawan,1998: 22). At the time of being established, the area was known as nieuwe wijk (Bruggen, 1998:43) which means new city. This naming indicates a residential area which was newly planned, where none previously existed. This residential area of Kotabaru was fully planned and prepared with modern concepts for the Dutch community. The street laneways were made orderly and houses were neatly arranged on the right and left of the roads (Boagers, 1983:81). The planning of the Kotabaru area applied the principles in the Garden City concept which had 


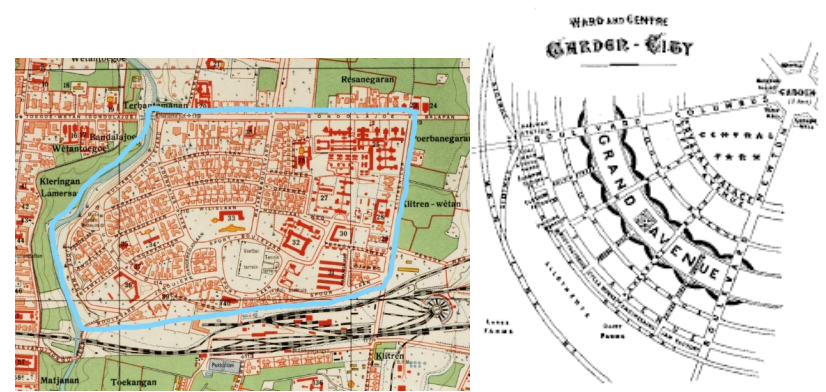

Figure 1. A 1925 Map of Kotabaru (left) source: Leiden Library which adopts the Garden City concept (right) source: Howard (1902)

been made popular by Howard at the beginning of the $20^{\text {th }}$ Century and had been adapted to the Dutch Indies environment which was then named Indische Koloniale Staad or often called Tropische Staad. This concept gave rise to the greater part being for park space, open space, the placing of houses further back from the road, and the separating of residential zones from office zones. This concept emphasizes the need for air circulation and good lighting systems for the interior of buildings related to the tropical climate in this area.

The Garden City concept of city residential areas, which emphasizes this garden city, according to the Culture Protection Area Act article 5 includes the provision of a protected cultural area if it is over fifty years old and rare as well as having important scientific values in accordance with article 7 of the Act. This form of residential area is the only one in Yogyakarta and has stood for more than 50 years with various components of the city (in the form of houses, offices, schools, places of worship and hospitals), street networks (in the form of boulevard, laan, and weg), green open spaces (in the form of fields and parks), and supporting facilities such as sporting venues which are still relatively well equipped. These things have given the Kotabaru protected cultural area a special and rare character. This is why Kotabaru area has an important value for science in particular the science of city planning and building forms and technology.

\section{Kotabaru has a Variety of Protected Cultural Areas}

Kotabaru has various buildings which are in the category of Protected Cultural Areas. Several of the cultural protected areas criteria according to the Republic of Indonesia Act No. 10 of 2011 Concerning Protected Cultural Areas are: a) 50 years or older b) Representing a period of style of at least 50 years c) having a special significance for history, science, education, religion, and/or culture, and d) having a cultural value for the strengthening of national identity.

There are forty-five buildings in the Kotabaru area which have a protected cultural status based on DIY Gubernorial Regulation (Keputusan Gubernur) No. 237/ KEP/2017, Keputusan Gubernur DIY No. 239/KEP/2017, and Keputusan Gubernur No. 195/KEP/2019. The variety of protected cultural sites in Kotabaru can be seen from their various types which consist of residential buildings, health buildings, education buildings, places of worship and support facilities buildings. Several of these buildings are, among others, Bethesda Hospital, Dr Soetarto Level III Hospital, BOPKRI I Senior High, State Junior High 5, Kotabaru Company Mess, Mr Djody Gondokusumo's Residence, Jalan Abubakar Ali 4 Residence, Yogyakarta City Tourist Agency Office, Code Museum (Museum Sandi), State Senior High 3 (SMA 3), Ungaran State Primary School 1 (SD 1), Batak Christian Huria Protestant Church (Gereja Huria Kristen Batak Protestan-HKBP), Saint Antonius Church, Sisters of Charity of Precious Blood Convent (Susteran Amal Kasih Darah), and a former Electricity Generating Plant.

Several buildings with the legal status of a protected cultural site to the present are still relatively intact and maintained. As a result, they are physical evidence which represents all the buildings in the Kotabaru protected cultural area. Based on the Protected Culture Area Act article 5 the existence of these buildings is important because their age is over 50 years and has important values for science in particular in relation to the special style of Indies buildings which emerged as an adaptation of European and local architecture. The values behind these buildings are important to be preserved and used for wider community interests in the present and in the future. Apart from the legal aspects, as protected cultural buildings it is important to protect the buildings from damage and illegal demolition.

\section{Kotabaru has an Historic Value of National Struggle}

One of the things that gives favour to the Kotabaru area as a protected cultural area is the remainders of historical events which occurred in the region. In the Dutch Colonial period the Kotabaru area provides historical evidence that the Yogyakarta Kraton played a major role in the provision of community facilities in the form of housing which was a need of the city community in Yogyakarta at the beginning of the $20^{\text {th }}$ century. The land used in the Kotabaru area was the property of the Yogyakarta Sultanate, and its permission had been obtained for its use as a residential area for the Dutch community at 
the time. Aside from that, in the period after Indonesia had proclaimed independence, the Japanese military government, did not immediately leave Yogyakarta. Kotabaru as the Japanese military centre in Yogyakarta was used for offices, military barracks, and a weapons storage warehouse. The most senior Japanese military official for Yogyakarta at the time, Butaico Major Otsuka, was occupying the former building owned by Nillmij (an insurance company in Yogyakarta) which then became the Office of Jiwasraya Insurance. On 6 October 1945 negotiations occurred between the leader of the freedom fighters Moh. Saleh Bardosono (as the General Chair of $\mathrm{KNI}$ ) with Major Otsuka concerning surrendering of arms owned by the Japanese forces. This event ended as an armed clash between Japanese forces with independence fighters in the Kotabaru area which occurred from 6-7 October 1945 (Suhartono, et al., 1983: 13-14; 24-25; Adrisijanti, Ed., 2014: 167). At the time of the battle, twenty-one Yogyakarta fighters fell. This battle signaled the surrendering of the Japanese in Yogyakarta which meant the freeing of the City of Yogyakarta from the hands of the Japanese military occupation government. This meant as a whole, Yogyakarta from that time was exclusively under the control of the Republic of Indonesia. To commemorate the service of the fighters who fell in this battle several street names, which originally had been taken from names of mountains and rivers, were replaced by the names of the fighters who had fallen at among others Jalan (Jl) Suroto, Jl Abu Bakar Ali, Jl Faridan M Noto, and Jl A.Jazuli. Apart from that, to commemorate these fighters the Yogyakarta community in 1952 had built a mosque in Kotabaru which was called Syuhada Mosque which refers to the fighters who had died in God's name to defend the freedom of the Republic of Indonesia (RI), which had just been proclaimed.

Several buildings in the Kotabaru area were once used for RI supporters after the moving of the RI capital city from Jakarta to Yogyakarta from 1946 to 1949 Several buildings functioned as offices among them Saint Ignatius College (Kolese St. Ignasius) which was used as the RI Defence Department Office. The Algemeene Middelbare School (AMS) building now Sekolah Menengah Umum Negeri 3 (General Secondary School) was used as student soldier accommodation. The house in Jalan Jenderal Sudirman was occupied by the first RI Justice Minister Mr Djody Gondokusumo. Meanwhile the Code Museum (Museum Sandi) was used as the Foreign Affairs Department office and the Department of Education, Teaching and Culture.

Various historical events associated with the existence of the Kotabaru area gives a picture that this area was not just of physical value but also has an important historic value, found primarily the history of the struggle of the Yogyakarta people's struggle in defending independence. The value of the struggle can still be remembered through monuments/special symbols of the invasion of Kotabaru, the use of street names in the Kotabaru area with the names of independence fighters, and the Syuhada Mosque building which was built to commemorate the independence fighters who fell as Muslim martyrs. These historic values are very important to be passed to the younger generation so an understanding of Kotabaru as the evidence of national struggle goes on and is properly conveyed.

\section{Kotabaru has an Intangible Heritage Potential}

The Kotabaru area not only has a wealth of cultural heritage in the form of the Garden City landscape and buildings but also has a wealth of cultural heritage which is intangible in nature. The intangible heritage potential at this time is in the form of cultural arts capabilities being developed by the Kotabaru community among others the traditional arts of dancing and the gamelan. Kotabaru is also included in the kelurahan (city district administrative unit) with cultural pilot projects which has been designated by the Yogyakarta City government. In 2020 the Kotabaru kelurahan staged a ketoprak (Javenese traditional theatre) with the play "Kembang Kamardikan" ("The Development of Independence"). The story staged is also related to the history of Kotabaru when the battle occurred in Kotabaru in defending independence in 1945. Several activities of modern art, which had been developing since 2010 in Kotabaru, was seen in the the staging of "Jazz Mben Senen" music. This activity was undertaken by the Kompas Group Institute of Royal Assistants for Culture (Lembaga Bentara Budaya Kompas Group) working with the Yogyakarta Jazz community to enliven artistic activities in Kotabaru. In the years 2017-2018 a sculpture exhibition in public space was conducted in Jalan Suroto boulevard, Jalan Faridan M Noto, Kotabaru. Meanwhile a regular annual activity, conducted by the Kotabaru kelurahan, is an allegorical parade to remember Indonesian independence. This activity is a cooperative effort of the kelurahan, the Kotabaru community and the Gondokusuman Sector Police (Sektor Polisi-Polsek) and the Military District Command (Komando Rayon Militer-Koramil) staff. Meanwhile food business activities in the form of cafes and street food vendors in the Kotabaru area are suitable to support the area's potential if it is properly developed and managed.

Various community activities characterised as 
intangible heritage certainly can support cultural richness as a result the Kotabaru region can remain living between its cultural heritage characterised as an object and as something intangible. Activities which integrate the two forms of cultural heritage can infuse a cultural soul between the past and the present without pushing out the other.

\section{Kotabaru as a Business and Services Area}

Data which can be tracked on Kotabaru area's dynamics of change are among others, in 1996 when it was recorded Kotabaru comprised thirty-one blocks with 269 houses (Umezu, 2001). Other data concerning Kotabaru (Purwoko, 2016) states that Kotabaru experienced a change of function from residential which at the beginning was $97 \%$ decreased to become almost $50 \%$. From the total of 312 buildings, as many as 136 were still functioning as residences. Meanwhile the use of buildings for commercial interests increased from year to year. In 1936 in the Dutch Colonial period building usage was $1.3 \%$, in 1993 it increased to $1.8 \%$ and 2004 it stayed at $1.8 \%$ (Yose, 2005). In 2007 it increased to $16 \%$ based on surveys undertaken by BPCB DIY, in 2011 increasing to $28.8 \%$ (Satya, 2011), 2016 saw it increase to $33 \%$ (Purwoko, 2016), and from a survey done by this writer in 2020 , the result was $38.1 \%$.

In parallel with Kotabaru's status as a business and service zone, quite significant increases can be seen in a building functions being a place of business. The emergence of these changes has resulted in the 'face' of Kotabaru gradually changing from its character as a residential area in the beginning to becoming both a residential area as well as a commercial area. This change has been spurred on by the location of the Kotabaru area which is in an elite residential area as a consequence is a location with a high sale value as a business location. Apart from that, the area is in a strategic location in the area of Jalan Jenderal Sudiriman which is a premium business area on the north side of the City of Yogyakarta. In fact, of the buildings which are in Jalan Jenderal Sudirman, not even one functions as a residence, all are changing to become buildings with a business or office function. Meanwhile the section of Jalan Suroto which is the main street in the Kotabaru area there is only one building which has a residential occupancy that is the official residence of the City of Yogyakarta deputy mayor, the remainder are business and office buildings. Based on the 2020 survey data the usage of buildings for business and office interests reached $38.1 \%$ of the total buildings in the Kotabaru area. By looking at the percentage change, the increases in usage as commercial buildings from year to year, it can be predicted that the Kotabaru area will change to be a business area unless managed by heeding cultural heritage conservation interests and so the character of the Indies buildings in the area will be lost.

Meanwhile the change on the community side is related to the changes from residential function to a business function spurred on by, among other things, the Buildings and Land Tax (pajak bumi bangunan-PBB) cost in the Kotabaru area. To reduce the high tax burden some in the community use their dwelling for use as a business space or a part is rented for use also as a business place. Several instances have emerged where the houses in the area have been sold because the person who has inherited it no longer lives there. Cases of buying and selling have also been spurred on a changing of building function to business interests.

The emergence of the Kotabaru area as a commercial area has finally become a problem that has to be thought through so it does not become a threat to conservation efforts for the Kotabaru area as a protected cultural area. The presence of a commercial area in Kotabaru has become basically and precisely an important matter in the dynamics of cultural heritage use. Often the conservation of cultural heritage only discusses the conservation of buildings without thinking about its function which is adjusted with changes in the period.

\section{Differences of Interest Which Arise}

Various conflicts of interest which arise are caused by two differences between the interests of a protected cultural area which strives to protect the area from damage and the other interest as a commercial area which places an emphasis on the usage of buildings as a place of business. As an example, in 2010 a problem arose with the demolition of an ancient building in Jalan Jenderal Sudirman which was on the cultural heritage list. Protests were lodged by Madya, a Non-Government Organization which demanded a cessation of work before there was clarification of discussions concerning this building. The building was to be used as a Pizza Hut fast food restaurant (Kompas.com, 16 June 2010). The second case was in 2018 with the demolition of house in Jalan Juwadi 7, Kotabaru. The demolition was considered to damage the image of Kotabaru as a protected cultural area (Jogja.antara.com, 8 Maret 2018). Another case which occurred was the construction of the eight storey Grha Eklin building at Jalan Suroto 3, Kotabaru in 2018. The construction of the building attracted attention because of the height of the building was 32 meters, the highest building in the Kotabaru area. If reference is made to the existing regulations a building is permitted at a maximum 
height of 32 meters based on Mayoral Regulation (Peraturan Walikota) No. 53 of 2017 because Kotabaru was in a business and services zone. Meanwhile if reference is made to the conservation of protected cultural areas. The most recent similar case which occurred in 2020 is associated with building height is the planned construction of Grha Padmanaba SMA 3 Yogyakarta which is located in the Kotabaru area. The plan is for a seven storey building. From the side of conservation regulations, the height of the building is considered will damage the image of the Kotabaru area although according the regulation on height it is not contrary to a business and services area (Jogja Suara.com, 3 September 2020).

From these various cases which have arisen from demolition and changing of the form of the building a conflict of interests has emerged between efforts for conservation of protected cultural areas with usage by commercial interests. This matter disadvantages conservation interests because it leads to a loss of buildings as a consequence of demolition and causing the changing of the form of the building which is not adapted to regulated norms of conservation. Although on the other hand these two interests have a strong and legal regulatory basis that is Pergub No 186/2011 which strives for the conservation of the Kotabaru area as a protected cultural area whereas Perda Kota Yogyakarta No. $1 / 2015$ Concerning RDTR and Perwal No. 53/2017 concerning the maximum height of buildings affirms the Kotabaru area is a business and services zone which allows the height of buildings to a maximum of 32 meters.

Until now efforts to resolve conflicts of interest are not seriously undertaking by government both the DIY and City of Yogyakarta governments. Various resolutions of these cases have favored commercial interests. It can be ascertained if this matter continually occurs then a conflict of interests will continually occur which in the end the conservation of the protection of cultural areas will lose its richness of protected cultural areas and the character of residential area with its Garden City concept. In the end the identity of the area will be damaged and lost which certainly will mean the loss also of the historical physical evidence of the people's struggle in opposing the Dutch colonialists.

\section{Understanding Kotabaru as a Protected Cultural Area Concurrently as a Commercial Area}

Differences in perspective to a problem will create differences in understanding which are also varied.
In the Kotabaru protected cultural area the involved parties certainly have varying interpretations (Thorsby, 1996:6; Byrne et al., 2001:55). There is an understanding particularly by government that the cultural heritage in a protected cultural area is a legacy of the Colonial period which has a uniqueness with its Garden City concept and various buildings which have an Indies architecture which require preservation. Apart from this, the Kotabaru area is also historic evidence of the Indonesian nation's struggle in defending its independence with the battle of 7 October 1945 as well as supporting the moving of the RI capital to Yogyakarta from 1946-1950. Meanwhile from another side, several communities which live in the Kotabaru area, understand this cultural heritage as a part of their memories and also an understanding of their assets having an economic value so the using of dwellings as a place of business is ever increasing. Another interpretation is that belonging to a part of the community through the Kotabaru Institute of District Level Community Empowerment (Lembaga Pemberdayaan Masyarakat Kelurahan-LPMK), is that cultural heritage in the protected cultural area can also be a potential asset in the tourist and creative economy industry. They also have planned a tourist program in the Kotabaru area through the heritage tourist trail.

To accommodate various differents understandings of the parties involved toward cultural heritage in the Kotabaru area an interpretation using the four components of the HUL will be used:

\section{Regulation System}

The government, in this regard, the DIY Cultural Office with Pergub 186/2011 Concerning Protected Cultural Areas, considers that the Kotabaru area is an invaluable asset from an historical, archeological, landscape and architectural perspective as a result it is appropriate for it to be designated as a protected cultural area needing to be preserved. Meanwhile the government, in this regard, the City of Yogyakarta Public Works Office with Perda No. 1/2015 Concerning RDTR views that the Kotabaru area can be used as a business and services areas because of its strategic location, in the area of Jalan Jenderal Sudirman, which is growing as a business and services zone. The consequence is this area will be adapted with the needs associated with business and services such as changes to the form of buildings and the use of signs for names and advertisements to support these needs. In the current conservation paradigm concept, enabled by the use of cultural heritage for present interests, including business and services, means commercial interests can be accommodated within it. In article 85 
of Act No. 11 of 2010 Concerning Protected Cultural Areas that commercial functions for protected cultural areas can be accommodated by continue to pay heed to conversation norms. In fact, the DIY government has issued a regulation concerning architecture which has DIY special characteristics in DIY Perda No. 1 of 2017 and Gubernatorial Regulation No. 40 of 2014 Concerning the Integration of New Building Architecture with a Nuance of Regional Culture. Based on these regulations that each new development permission or building renovation in the Kotabaru protected cultural area is specially regulated concerning its form and must get a recommendation from the Cultural Heritage Conservation Advisory Council (Dewan Pertimbangan Pelestarian Warisan BudayaDP2WB) through the DIY Cultural Office. In these regulations new developments and renovations are very possible, on condition it continues to heed conservation norms. This shows that there is an effort to accommodate both these interests in particular in the Kotabaru protected cultural area.

The existing regulatory instrument has clearly given a means as to how, between conservation and new development and renovation, a satisfactory accommodation can be reached. A problem which often arises is precisely that the socialization of these various regulations falls short of what is needed as a result, there are still many communities which have not yet been informed giving rise to conflict when new development or building renovations are being undertaken in the Kotabaru area. Efforts to maximize the socialization of the existing regulations needs to be done more intensively for the entire community living in the Kotabaru area. It would be more ideal if these regulations also needed to obtain input from the community if it was felt there was a need for a change to the regulations in conjunction with the development of requirements for management in the Kotabaru area. Revisions of these regulations could be done prior by the various interested parties sitting down together such as government in the cultural and urban planning fields, the community and business groups and agree to various matters related to the use of space and buildings in the Kotabaru area. In this way, new regulations which are made, are not stove piped in accordance with respective interests.

\section{Community Engagement}

Presently the community living in the Kotabaru area have a variety of understandings also. Several understand the houses in Kotabaru are necessary to be preserved because they have a value in memories for the residents and are an inheritance from parents which need to be protected as a house passed down (interview with Ibu Esmeraldayanti, a Kotabaru resident). One of the residents was also proud of the presence of protected cultural buildings.

I am very happy and proud of the convent accommodation because it has a high historic value and is full of remembrances. Only the cost of building maintenance is very expensive and it cannot be changed arbitrarily. (Sister Friska, who lives in the Kotabaru Sisters of Charity of Precious Blood)

On the other hand, the community also has an understanding that they can use the buildings in the Kotabaru area as business place so as to be able to get an economic benefit although they still maintain the form of the building. Several community groups also consider that Kotabaru can be used not only as a place to live in fact it could be planned to become a heritage tourist area (interview with Bapak FX Supardi, Chair, Kotabaru Institute Representing Kampung Communities (Lembaga Perwakilan Masyarakat Kampung-LPMK).

At present the involvement of the community is very limited because of the domination of the government role which is very strong in the management of the Kotabaru area. The government does not often involve the community in the management of the Kotabaru area. Existing community institutions such as the Neighborhood Organization (Rukun Tetangga-RT), Residents Organization (Rukun Warga-RW) and the LPMK know little about the government programs in the Kotabaru area. Even information on the status of protected cultural buildings in the Kotabaru area is not sought, meanwhile the government has designated fortyfive buildings in the Kotabaru area as protected cultural buildings through gubernatorial decrees. The result is the community is more often passive in the management of the Kotabaru area as a protected cultural area. Based on the HUL approach the involvement of the community is absolutely required in the management of the cultural heritage. The collaboration between the government and community including business groups is expected will minimize conflicts which occur because each has the same responsibility to manage the Kotabaru area so that the interests of conservation and commerce can be suitably accommodated.

\section{Knowledge and Planning}

The Kotabaru area at this time can be seen to be experiencing many changes physically and functionally primarily in the emergence of new buildings which 
architecturally have a different character to the Kotabaru special Indies architecture. In the case of the section of Jalan Suroto are found new buildings which have modern architecture which are very different to the Indies architecture among others, Graha Eklin, LBC Beauty Skin Centre, the City of Yogyakarta Library, Silol Restaurant, the Bulog Office and Telkomsel Office. In the meanwhile, in the section of this road are found nine buildings with a commercial function with architecture that has been changed from its original. This matter, if it is not well regulated and planned going forward it will damage the Kotabaru area image as an area which has Indies special characteristics.

Other data shows that apart from the architectural changes which are inappropriate, there are also found several buildings which can made into examples of how to use buildings for commercial interests and make physical changes to the building but still maintain the character of the original building. Several examples are among others, Café Legend, Fast Food Restaurant Richeese, BTN Bank Syariah, Notaris Jeny Office, Kucala Medical Centre, and Toga Mas Book Shop. These various examples give a picture that knowledge concerning the way of viewing the cultural heritage in the Kotabaru area varies. To unify the two interests then what is needed is the making of an equivalent pattern of thinking which can accommodate both. In this way if the concept of knowledge concerning how to unite two different interests is jointly understand then the problem which arises in the Kotabaru area can be resolved without causing a loss to one another.

Subsequent steps after basic knowledge is understood by the government, community, and business people is a need for management planning efforts. The several stepped phases of cultural heritage management based on the HUL approach (Bandarin dan Oers, 2012) are among others: 1) to make an assessment of natural resources, culture and people who in the Kotabaru area, 2) to involve all stakeholders who are connected to the Kotabaru area to decide joint objectives to be achieved, 3) do an assessment of the level of threat to the cultural heritage and the impact on social-economic change in the Kotabaru area, 4) integrate cultural heritage values in the context of Kotabaru area development, 5) make a special conservation policy in the Kotabaru area, 7) develop coordination between stakeholders who have differing interests.

This planning strategy is felt to be more comprehensive in managing the Kotabaru area cultural heritage because of the various elements involved and thinking about threat prediction and changes that will arise in relations to commercial interests. Apart from that it is necessary for there to be a specific local manager to develop the Kotabaru cultural heritage area who accommodates cultural heritage conservation interests and commercial interests even Kotabaru community socio-cultural interests. In this way there is a solidarity to achieve joint aims which can be realized without causing a loss to each other.

\section{Finance}

The financial concept in the management of the Kotabaru area can be done by involving various parties. Currently the financing of Kotabaru area development is more often done by the government. The concept of financing, which is dominated by this one party results in an imbalance of roles between the involved parties. The DIY government based on Act No.13 of 2012 Concerning the DIY Special Characteristics gets a Special Characteristics Fund (Dana Keistimewaan-Danais) from the central government. At this time, one of the uses of the Danais is for interests related to culture. The use of this fund which has been done for cultural matters in the Kotabaru protected cultural area is among others is for physical activities such as the maintenance of SMS 3, The Santo Ignatius Church, the determination of building status and protected cultural sites in the Kotabaru area, and the development of pedestrian management in the Jalan Suroto section. In this matter, the community is not often involved to participate in funding for the management of the Kotabaru area as a result the community does not know much about financing problems for the area. In the meantime, other parties, which in fact are very likely to be involved in financing, are private parties or investors who can support the development and developing of the Kotabaru area. With its function as a commercial area, it is very possible to involved private parties or investors to play a role in the developing of the Kotabaru area. So far investor groups have been involved in development of the Kotabaru area but they still operate individually without being involved in the managing of the Kotabaru area which accommodates various existing interests.

Efforts which have been undertaken with the financing of Kotabaru area's management are largely limited to the government's role. Meanwhile financing by the government in particular, the special characteristics fund has a limitation because of the various regulations affecting the distribution of these funds. The funds cannot extend to building maintenance in particular, for individuals connected to the existing regulations. In this way individually owned houses which have been designated as protected cultural houses cannot be funded by the special characteristics fund because of the 
system in force. Meanwhile if the funding involves many parties both the community itself or investor groups then problems such as these can be minimized.

From the four elements, which become indicators of cultural heritage management based on HUL, basically they are already there. It means between the elements of the regulatory system, the involvement of the community, knowledge and planning, and the funding have become a part of cultural heritage management in Kotabaru Yogyakarta. Despite this, each element is still very limited and is not yet well managed. There is no coordination and effort which brings together all three stakeholders that is, the government, community and investors to sit together to discuss cultural heritage management. It is very possible for a cultural heritage managing board to be formed in Kotabaru with its membership coming from government, the community and investors as a result it would be expected various interests would be accommodated which would minimize various conflicts of interest occurring.

\section{CONCLUSION}

The Kotabaru area in Yogyakarta, which has been designated a protected cultural area, faces various challenges in its conservation efforts. At present, developments have called for changes in the Kotabaru area, as community activities are becoming increasingly complex. These changes are things that are unavoidable. Conflicts of interest occur as a consequence of the lack of a system capable of responding to the challenges which arise. Basically, conservation and commercial interests can be made to reach a compromise to achieve a joint aim. The HUL approach is one solution to these problems because it has the comprehensive elements to resolve differences of interest problems. One of the main keys is involving stakeholders, from the government, local community, and businesspeople or investors, to jointly think through the objectives they wish to achieve together In this way, the domination of regulations as the basis for conflict resolution is not effective enough. Instead, what is needed are regulations that can accommodate various interests as a result, where stakeholders are not being positioned in opposition to one another.

\section{ACKNOWLEDGEMENT}

This paper is a small part of a dissertation research in the Humaniora study program, Cultural Sciences Faculty, Universitas Gadjah Mada Yogyakarta. The writer expresses gratitude to assistance provided his supervisor,
Dr Mahirta, MA and co-supervisor Dr Tular Sudamadi, MA for the guidance in the writing of the dissertation which finally the writer realized in this paper. The writer also expresses appreciation to the Republic of Indonesia Ministry of Education and Culture for providing an LPDP scholarship for the writer to undertake a doctoral program studies.

\section{REFERENCES}

Adrisijanti, Inajati dan Anggraeni (Ed) (2014). Mosaik Warisan Budaya Yogyakarta. Yogyakarta Balai Pelestarian Cagar Budaya Yogyakarta.

Asriana \& Sesotyaningtyas (2018). Pendekatan Historic Urban landscape Untuk Pelestarian Kawasan Kampung Al-Munawar 13 Ulu, Palembang. Temu Ilmiah Ikatan Peneliti Lingkungan Binaan Indonesia (IPLBI) 7, J051-057.

Bandarin, F dan R. van Oers (2012). The Historic Urban Landscape: Managing Heritage in Urban Century. West Sussex: Viley; Blackwell.

Bogaers, E. \& Ruijter, P. de (1986). Ir Thomas Karsten and Indonesian Town Planning, 1915-1940. In P.J.M. Nas (Ed.), The Indonesian city (pp. 71-88). Dordrecht: Foris.

Bruggen, M.P. van \& R.S. Wassing (1988). Djokja En Solo: Beeld van de Vorstensteden. Asia Maior.

Byrne, D. (2001). Social Significance: A Discussion Paper. NSW National Park and Wildlife Service.

Daldanise Gaia (2016). Innovative Strategies of Urban Heritage Management for Sustainable Local Development. Procedia-Social and Behavioral Sciences, 223.

Darvill, T. (1987). Ancient Monuments in the Countryside: An Archeological Management Review. London: Historic Building and Monuments Commission for England.

Dinas Sosial Propinsi Daerah Istimewa Yogyakarta (1983). Replika Sejarah Perjuangan Rakyat Yogyakarta. Yogyakarta: Dinas Sosial Provinsi DIY.

Dingemans, L.F. (1926). Gegevens over Jogjakarta 1926, Vol. A. Djogjakarta: H. Bunning.

Hadiyanto Eko (2017). Konservasi dan Pengendalian Kotabaru. Bulletin Mayangkara, 4. Dinas Kebudayaan DIY.

Hodder, I. (1998). The past as passion and play Catalhoyuk as a site of conflict in the construction of multiple pasts. In Lynn Meskell (Ed.), Archaeology Under Fire: Nationalism, Politics and Heritage in the Eastern Mediterranean and Middle East (pp. 124139). London: Routledge.

Howard, E. (1902). Garden Cities of To-Morrow. London, Swan Sonnenschein \& Co., Ltd. Paternoster Square. 
Ikaputra (2017). Kotabaru Garden City Ing Ngayogyakarta Bulletin Mayangkara, 4. Dinas Kebudayaan DIY.

Junawan, M. (1998). Kotabaru: Pola Pemukiman Masyarakat Belanda di Kota Yogyakarta Tahun 1899-1936. Skripsi. Fakultas Ilmu Budaya, Universitas Gadjah Mada.

McGimsey, C.R. \& H. Davis (Ed) (1977). The Management of Archaeological Resource, the Airlie House Report. Special Publication of the Society for American Archaeology.

McKercher, B., \& du Cros, H. (2002). Cultural Tourism: The Partnership Between Tourism and Cultural Heritage Management. New York: Routledge.

Prabowo, B.N., Pramesti, P.U., \& Sukawi, S. (2020). Historic Urban Landscape (HUL) approach in Kota Lama Semarang: Mapping the Layer of Physical Development Through the Chronological History. IOP Conference Sereies: Earth and environtmental Science, 402. The $3^{\text {rd }}$ International Conference on Sustainability in Architectural Design and Urbanism.

Puczkó, L.A.S.Z.L.O. (2006). Interpretation in Cultural Tourism. In Smith, M. \& Robinson, M. (Ed.), Cultural Tourism in a Changing World: Politics, Participation and (re) presentation (pp.227-244). Bristol: Channel View Publications.

Rátz, T. (2006). Interpretation in the house of terror, Budapest. In Smith, M. \& Robinson, M (Ed.), Cultural tourism in a changing world: Politics, participation and (re) presentation (pp. 244-56). Bristol: Channel View Publications.

Rauzi, E. N. \& Dewi, C. (2017). Historic Urban Landscape: Its Possibilities and Challenge in Banda Aceh. Proceeding International Conference on Rebuilding Place-AVAN.

Suparwoko \& Lagonah (2016). Change Analysis of the Cultural Heritage Building Function and Facade in Kotabaru, Yogyakarta, Indonesia. ICSB.

Throsby, D. (1999). Cultural Capital. Journal of cultural economics, 23(1-2), 3-12.

Timmer, P. (2019). New Horizone for Old Tin Mining Town, HUL Quick Scan Muntok West Bangka. Cultural Heritage Agency of the Netherlands.

Umezu, H. Y. S. (2001). Studi Perubahan Urban Fabric di Kawasan Pemukiman Belanda (Studi Kasus Kotabaru, Yogyakarta). Tesis. Magister Perencanaan Kota dan Daerah, Universitas Gadjah Mada.
UNESCO (2016). The HUL Guidebook: Managing Heritage in Dynamic and Constantly Changing Urban Environments. A Practical Guide to UNESCO Recommendation on the Historic Urban Landscape. http:/historicurbanlandscape.com/themes/196/ userfiles/download/2016/6/7/wirey5prpznidqx.pdf

Wahyu, T. H. (2011). Pelestarian dan Pemanfaatan Bangunan Indis di Kawasan Kota Baru. Tesis. Fakultas Ilmu Budaya, Universitas Gadjah Mada.

Yose, I. W. M. (2005). Kajian Pengendalian Pemanfaatan Ruang Di Kawasan Bersejarah: Kasus Kota Baru Yogyakarta. Tesis. Magister Perencanaan Kota dan Daerah, Universitas Gadjah Mada.

\section{Regulation}

Keputusan Gubernur DIY No 237 Tahun 2017 Tentang Tentang Penetapan Bangunan di Kelurahan Kotabaru, Kecamatan Gondokusuman Sebagai Cagar Budaya.

Keputusan Gubernur DIY No 239 Tahun 2017 Tentang Penetapan Bangunan di Kelurahan Kotabaru, Kecamatan Gondokusuman Sebagai Cagar Budaya.

Keputusan Gubernur DIY No 195 Tahun 2019 Tentang Bangunan di Kelurahan Kotabaru, Kecamatan Gondokusuman, Kota Yogyakarta Sebagai Bangunan Cagar Budaya.

Peraturan Daerah DIY No 1 Tahun 2015 Tentang Rencana Detail Tata Ruang dan Peraturan Zonasi Kota Yogyakarta Tahun 2015-2035.

Peraturan Daerah DIY No 6 Tahun 2012 Tentang Pelestarian Warisan Budaya.

Peraturan Daerah DIY No 1 Tahun 2017 Tentang Arsitektur Berciri Khas Daerah Istimewa Yogyakarta.

Peraturan Gubernur DIY No 40 tahun 2014 Tentang Panduan Arsitektur Bangunan Baru Bernuansa Daerah.

Peraturan Gubernur DIY No 186 Tahun 2011 Tentang Kawasan Cagar Budaya DIY.

Peraturan Walikota Yogyakarta No 25 Tahun 2013 Tentang Koofisien Dasar Bangunan.

Peraturan Walikota Yogyakarta No 53 Tahun 2017 Tentang Ketinggian Bangunan di Kota Yogyakarta.

Undang-Undang RI No 11 Tahun 2010 Tentang Cagar Budaya.

Undang-Undang RI No 13 Tahun 2012 Tentang Keistimewaan DIY. 